Article

\title{
Efficient One-Step Immobilization of CaLB Lipase over MOF Support $\mathrm{NH}_{2}$-MIL-53(A1)
}

\author{
Victoria Gascón-Pérez ${ }^{1,2, * \mathbb{C}}$, Mayra Belen Jiménez ${ }^{1}$, Asunción Molina ${ }^{1}$, Rosa María Blanco ${ }^{1}$ \\ and Manuel Sánchez-Sánchez ${ }^{1, *(D)}$ \\ 1 Instituto de Catálisis y Petroleoquímica (ICP), CSIC, C/ Marie Curie, 2, 28049 Madrid, Spain; \\ mayrabelen_jimenez@outlook.com (M.B.J.); asuncion.molina@csic.es (A.M.); rmblanco@icp.csic.es (R.M.B.) \\ 2 Department of Chemical Sciences, Bernal Institute, University of Limerick, V94 T9PX Limerick, Ireland \\ * Correspondence: Victoria.GasconPerez@ul.ie (V.G.-P.); manuel.sanchez@icp.csic.es (M.S.-S.)
}

Received: 23 May 2020; Accepted: 7 August 2020; Published: 10 August 2020

\begin{abstract}
Metal-organic framework (MOF) materials possess the widest versatility in structure, composition, and synthesis procedures amongst the known families of materials. On the other hand, the extraordinary affinity between MOFs and enzymes has led to widely investigating these materials as platforms to support these catalytic proteins in recent years. In this work, the MOF material $\mathrm{NH}_{2}-\mathrm{MIL}-53(\mathrm{Al})$ has been tested as a support to immobilize by one-step methodology (in situ) the enzyme lipase CaLB from Candida antarctica by employing conditions that are compatible with its enzymatic activity (room temperature, aqueous solution, and moderate $\mathrm{pH}$ values). Once the nature of the linker deprotonating agent or the synthesis time were optimized, the MOF material resulted in quite efficient entrapping of the lipase CaLB through this in situ approach $(>85 \%$ of the present enzyme in the synthesis media) while the supported enzyme retained acceptable activity ( $29 \%$ compared to the free enzyme) and had scarce enzyme leaching. The equivalent post-synthetic method led to biocatalysts with lower enzyme loading values. These results make clear that the formation of MOF support in the presence of the enzyme to be immobilized substantially improves the efficiency of the biocatalysts support for retaining the enzyme and limits their leaching.
\end{abstract}

Keywords: CaLB lipase; enzyme immobilization; in situ; $\mathrm{MOF}$ support; nanocrystalline; $\mathrm{NH}_{2}-\mathrm{MIL}-53(\mathrm{Al})$; one-step; post-synthesis

\section{Introduction}

Immobilized lipases are currently used in many processes, most of them related to the pharmaceutical industry due to their enantioselectivity. Among many others, typical examples are the enantiomeric esterification of captopryl (antihypertensive) or the aryl propionic analgesics such as (S)-naproxen. The immobilization of lipases to lead solid biocatalysts is essential for their applications as it allows their stabilization and easy recovery from the liquid reaction media and subsequent reuse.

The discovery of permanent porosity in certain thermally-stable coordination polymers, the so-called metal-organic frameworks (MOFs) [1-4], at the end of the last century, probably gave rise to the greatest ever revolution in the field of porous materials. MOFs are nanoporous coordination polymers, generally but not always crystalline, formed by either isolated metal ions or metal clusters linked by multidentate (at least, bidentate) organic ligands given rise to structures extended along two or three spatial dimensions [5]. Indeed, more than 90,000 MOF materials have been described in two decades [6,7], involving a diverse selection of metals and numerous organic linkers. The extraordinary versatility of MOFs is not only structural or compositional but also in terms of synthesis methods $[8,9]$, 
which contrasts with the almost monotonous hydrothermal procedures used in the synthesis of inorganic microporous materials.

Amongst the numerous potential applications of MOFs, their use as enzyme supports has awakened the interest of the scientific community in the past few years [10-17], particularly since the intrinsic pore size of MOFs does not have to be necessarily larger than the enzyme size [18-24].

Owing to the initial pore size limitation (only enzymes of a certain dimension could be encapsulated within a MOF) as reported by Ma et al. [25-28], other methodologies were developed in an attempt to universalize the enzymatic immobilization of MOFs. By taking advantage of: (i) The favourable chemical affinity between the MOF materials and enzymes [18], (ii) the possibility of preparing the MOFs supports under enzymatically compatible conditions, which enables the enzyme immobilization within or onto the surface of the MOF material in one step [18-22], or (iii) the chance of using the enzyme as the organic linker for the MOF material [24], therefore many methodologies of preparing MOF-supported solid biocatalysts were rapidly and simultaneously developed by different research groups.

The synthesis of some carboxylate-based MOF materials, which are the most common MOFs to support enzymes, can be readily carried out in aqueous solutions at room temperature by employing a deprotonating agent to solubilize the insoluble carboxylate acid [29-33]. In addition, some of the so-formed MOFs can be crystallized in the nanometre scale, which could have important advantages in particular applications such as heterogeneous catalysis. Moreover, they possess very high external surface areas [29] that favour their interaction with any macromolecules (for instance, enzymes). This fact, together with the natural chemical affinity of the enzyme for the MOF [18], makes the in situ approach for enzyme immobilization onto MOF-based supports a very efficient method [19-24]. Furthermore, immobilization is presumably non-covalent, so minor activity loss against that of the free enzyme could be reached.

One of the nanocrystalline MOF materials able to be prepared under these sustainable conditions is the $\mathrm{X}-\mathrm{MIL}-53(\mathrm{Al})$, where $X$ denotes an organic functional group (such as $-\mathrm{H},-\mathrm{NH}_{2}$ or $-\mathrm{NO}_{2}$ ) $[29,30]$. The structure of the as-prepared $\mathrm{NH}_{2}$-functionalized MIL-53(Al) shown in Figure A1, evidences that their pores, which are of limited sized and filled by a protonated organic linker cannot play any role in the encapsulation of comparatively much larger lipase $\mathrm{CaL} \mathrm{B.} \mathrm{NH}_{2}$-functionalized MIL-53(Al) was already identified as an acceptable in situ support for the enzyme $\beta$-glucosidase $[20,21]$, whose immobilization is rather a challenge due to its large dimensions. In that study, it was confirmed that the presence of the enzyme in the synthesis medium altered the chemistry of the MOF material, which was formed together with the protonated organic linker. Nevertheless, the phase responsible for the $\beta$-glucosidase immobilization was undoubtedly the MOF-based one.

In this study, the validity of this in situ one-step methodology for enzyme immobilization onto $\mathrm{NH}_{2}-\mathrm{MIL}-53(\mathrm{Al})$ is extended to lipase CaLB (from Candida antarctica), which indeed is one of the most widely investigated enzymes in different immobilization processes [34-36]. Apart from our own studies using nanocrystalline $\mathrm{NH}_{2}$-MIL-53(Al) supports for enzymes [20,21], the MIL-53(Al) family has proved to be efficient in the immobilization of: (i) Laccase on $\mathrm{NH}_{2}-\mathrm{MIL}-53(\mathrm{Al})$, using our one-step room-temperature methodology [37]; (ii) laccase on meso-MIL-53(Al) by post-synthesis methods [38]; and (iii) luciferase on non-functionalized MIL-53(Al), also by post-synthesis methodology [39]. We also found excellent results for lipase in situ immobilization on the semi-crystalline support Fe-BTC [23], suggesting that this enzyme could be easily immobilized onto MOF supports. In spite of the fact that Fe-BTC resulted in an excellent support for lipase, it is worth investigating any other MOF-based support for this enzyme such as the $\mathrm{NH}_{2}-\mathrm{MIL}-53(\mathrm{Al})$ considered in this work. On one hand, this support has a crystalline-enough structure that allows to properly understand the lipase-MOF interaction and, on the other hand, it is basically inert from a catalytic point of view. In addition, employing $\mathrm{NH}_{2}$-MIL-53(Al) support for lipase immobilization allows extending the state-of-the-art over a previous immobilization approach [21-23]. Different in-solution deprotonating agents such as sodium hydroxide $(\mathrm{NaOH})$, triethylamine (TEA), or ammonium hydroxide $\left(\mathrm{NH}_{4} \mathrm{OH}\right)$ are studied here for generating lipase-based solid biocatalysts with $\mathrm{NH}_{2}$-MIL-53(Al) as the crystalline support. The efficiency of 
the lipase immobilization as well as the activity of the resultant biocatalyst is compared with their counterparts containing the enzyme $\beta$-glucosidase.

\section{Results and Discussion}

\subsection{In Situ Immobilization of Lipase on $\mathrm{NH}_{2}-\mathrm{MIL}-53(\mathrm{Al})$}

The choice of both $\mathrm{NH}_{2}-\mathrm{MIL}-53(\mathrm{Al})$ as the support and the in situ approach as the main strategy for the enzyme lipase CaLB immobilization for this work was based on previous results achieved by systematic studies over the immobilization of $\beta$-glucosidase performed in our laboratory $[20,21]$. In these studies, parameters such as the nature of the linker deprotonating agent $(\mathrm{NaOH}$, ammonia or trimethylamine) or synthesis time (1-48 h) strongly influenced the phase formed, the enzyme immobilization efficiency, and enzymatic activity $[20,21]$. As a result, these parameters have been methodically investigated for the immobilization of the enzyme lipase CaLB (Table 1). As shown in Table 1, on the one hand, the percentage of immobilized lipase (Enz. immob. (\%)) was obtained via the Bradford assay by giving the differential enzyme concentration between the initial enzyme concentration offered to the synthesis media and the final concentration present in the supernatant after filtering and recovering of the resultant biocatalyst. As it can be seen, in all cases a percentage higher than $85 \%$ was obtained with respect to the enzyme present in the synthesis media. It is worth noting that this method does not consider if the enzyme keeps its activity during the immobilization process. On the other hand, the hydrolysis of $p$-NPA was used as a routine test for measuring spectrophotometrically at $348 \mathrm{~nm}$ and $25^{\circ} \mathrm{C}$ the nonspecific esterase activity during the process of in situ lipase immobilization in order to calculate the enzyme loading $\left(\mathrm{mg}^{-1} \mathrm{~g}^{-1}\right.$, column 3$)$. The enzyme concentration was calculated as the difference between the activity of suspension solution in the synthesis media and the remaining activity present in the supernatant after filtering and recovering of the resultant biocatalyst.

Table 1. Enzyme immobilization percentage, enzyme loading, catalytic activity, specific activity, and retained activity of different in situ biocatalysts Enz@MOF-DA-x, where DA is the deprotonating agent and $\mathrm{x}$ is the particular synthesis time.

\begin{tabular}{|c|c|c|c|c|c|}
\hline $\begin{array}{c}\text { In situ Lip@MOF } \\
\text { Biocatalyst }\end{array}$ & $\begin{array}{l}\text { Enz. Immob. } \\
\qquad \%)^{1}\end{array}$ & $\begin{array}{l}\text { Enz. Loading } \\
\left(\mathrm{mg} \cdot \mathrm{g}^{-1}\right)^{2}\end{array}$ & $\begin{array}{l}\text { Catal. Activ. } \\
\left(\mathrm{U} \cdot \mathrm{g}^{-1}\right)^{3}\end{array}$ & $\begin{array}{l}\text { Spec. Activ. } \\
\left(\mathrm{U} \cdot \mathrm{mg}^{-1}\right)^{4}\end{array}$ & $\begin{array}{l}\text { Ret. Activ. } \\
\quad(\%)^{5}\end{array}$ \\
\hline \multicolumn{6}{|l|}{ Lip@NH } \\
\hline$-\mathrm{NaOH}-1 \mathrm{~h}$ & 88 & 18 & 1218 & 68 & 29 \\
\hline$-\mathrm{NaOH}-3 \mathrm{~h}$ & 92 & 14 & 905 & 65 & 27 \\
\hline$-\mathrm{NaOH}-24 \mathrm{~h}$ & 99 & 19 & 1064 & 56 & 24 \\
\hline -TEA-3 h & 86 & 20 & 320 & 16 & 7 \\
\hline -TEA-24 h & 86 & 19 & 124 & 7 & 3 \\
\hline$-\mathrm{NH}_{4} \mathrm{OH}-3 \mathrm{~h}$ & 92 & 13 & 96 & 7 & 3 \\
\hline$-\mathrm{NH}_{4} \mathrm{OH}-24 \mathrm{~h}$ & 95 & 25 & 157 & 6 & 3 \\
\hline \multicolumn{6}{|l|}{ Lip@Fe-BTC- 7} \\
\hline$-\mathrm{NaOH}-10 \mathrm{~min}$ & 95 & 12.9 & 387 & 30 & 8 \\
\hline$-\mathrm{NaOH}-22 \mathrm{~h}$ & 87 & 10 & 3587 & 359 & 97 \\
\hline \multicolumn{6}{|c|}{$\beta G @ N_{2}-M I L-53(A 1)-{ }^{8}$} \\
\hline$-\mathrm{NaOH}-1 \mathrm{~h}$ & 33 & 28 & $6^{6}$ & $0.21^{6}$ & 3 \\
\hline$-\mathrm{NaOH}-24 \mathrm{~h}$ & 96 & 79 & $31^{6}$ & $0.39^{6}$ & 5.6 \\
\hline$-\mathrm{NH}_{4} \mathrm{OH}-24 \mathrm{~h}$ & 98 & 56 & $51^{6}$ & $0.91^{6}$ & 13.1 \\
\hline -TEA-48 h & 99 & 108 & $94^{6}$ & $0.87^{6}$ & 12.5 \\
\hline
\end{tabular}

1 Percentage of immobilized enzyme relative to the total amount of enzyme per gram of support present in the immobilization media. Method used: Bradford assay [40]. ${ }^{2}$ Milligrams of enzyme per gram of support. Tested reaction (lipase): Hydrolysis of $p$-NPA. ${ }^{3}$ Activity units per gram of support. Tested reaction (lipase): Hydrolysis of tributyrin (TB). ${ }^{4}$ Activity units per milligram of enzyme calculated as catalytic activity $\left(\mathrm{U}^{-g^{-1}}\right)$ against enzyme loading. $\left(\mathrm{mg} \cdot \mathrm{g}^{-1}\right)$. The activity of the corresponding free enzyme is given in brackets. Tested reaction: Hydrolysis of tributyrin (TB). ${ }^{5}$ Percentage of retained activity relative to the activity of the corresponding free enzyme. Reference activity of the enzymatic extract: $238 \mathrm{U} \cdot \mathrm{mg}^{-1}\left(\mathrm{C}=5.9 \mathrm{mg} \cdot \mathrm{mL}^{-1}\right) .{ }^{6}$ Activity units per gram of support. Tested reaction ( $\beta$-glucosidase): Hydrolysis of $p$-Nitrophenyl $\beta$-D-Glucopyranoside. ${ }^{7}$ Data taken from ref. [23]. ${ }^{8}$ Data taken from ref. [21]. 
The enzyme loading in these biocatalysts is around $20 \mathrm{mg} \cdot \mathrm{g}^{-1}$, and the variations of the loading found amongst the different biocatalysts was due to the differences in the yield of the MOF support. For a given deprotonating agent $\left(\mathrm{NaOH}, \mathrm{TEA}\right.$, or $\left.\mathrm{NH}_{4} \mathrm{OH}\right)$, the percentage of immobilized enzyme was increased or at least maintained with the synthesis time. On the contrary, the specific catalytic activity (activity per mg of immobilized enzyme) was shown to slowly decrease with time. This could be the result of the enzyme having been exposed for a prolonged period of time to the synthesis media designed for the MOF formation or because the first immobilized lipase molecules could become more inaccessible to the substrates if the support particles continue growing over time. Supporting this last possibility, the crystalline order of the samples inferred by powder X-ray diffraction (PXRD) characterization seems to improve with the extended reaction synthesis time (Figure 1), suggesting a better (and probably more hindered) integration of the enzyme within the MOF.

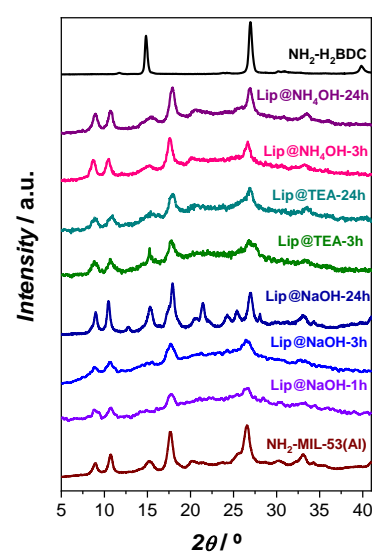

Figure 1. Normalized PXRD patterns of free-enzyme $\mathrm{NH}_{2}-\mathrm{MIL}-53(\mathrm{Al})$ (wine line, at the bottom), of the protonated linker $\mathrm{NH}_{2}-\mathrm{H}_{2}$ BDC (black, at the top) and the in situ biocatalysts Lip@ $\mathrm{NH}_{2}-\mathrm{MIL}-53$ (Al)-DA-x prepared with different deprotonating agents $\mathrm{DA}(\mathrm{NaOH}, \mathrm{TEA}$, or $\mathrm{NH} 4 \mathrm{OH})$ and after different synthesis times $\mathrm{x}$ (from 1 to $24 \mathrm{~h}$ ).

Table 1 also shows the immobilization results of the same enzyme CaLB lipase on the semi-crystalline MOF Fe-BTC under similar conditions (one-step/in situ procedure, at room temperature, in the presence of a base $(\mathrm{NaOH})$ acting as a deprotonating agent of the corresponding organic linker, etc.) [23]. Using such MOF material as support, both high enzyme immobilization efficiency and high specific catalytic activity of the resultant biocatalysts were also reached, being even higher under certain conditions with respect to the catalysts of the present study. Nevertheless, it must be considered that both MOF supports are complementary in certain aspects: (i) Unlike the semi-amorphous nature of MOF Fe-BTC material, the $\mathrm{NH}_{2}$-MIL-53(Al) material is crystalline, which both allowed a more precise study and a better understanding of the possible interaction MOF-enzyme; on the contrary, the structure of semi-amorphous Fe-BTC could not be solved, and the presence, concentration, and/or location of the defects or metal centers interacting with the enzyme could be random and therefore, hard to control from an experimental point of view; (ii) the support $\mathrm{NH}_{2}-\mathrm{MIL}-53$ (Al) is basically inert in terms of catalysis, as their amino groups have no basic character because they are directly bonded to an aromatic ring, whereas Fe-BTC has already shown its (photo)catalytic potential in various types of reactions $[32,41,42]$, which could potentially be masking the intrinsic biocatalytic activity carried out by the supported enzyme. In summary, the study of both systems, Lip@ $\mathrm{NH}_{2}-\mathrm{MIL}-53(\mathrm{Al})$ and Lip@Fe-BTC, is somehow complementary and convenient for extending the state-of-the-art with respect to said systems, and it should not be seen as a strict competition.

In order to detect the crystalline phases present in the biocatalyst, a powder X-ray diffraction (PXRD) characterization technique was employed. In this regard, in our previous work [21], it was reported that solid biocatalysts containing $\beta$-glucosidase supported on the same MOF material than the herein employed $\left(\mathrm{NH}_{2}-\mathrm{MIL}-53(\mathrm{Al})\right)$ using the same procedure. That approach showed the presence 
of the protonated linker $\mathrm{NH}_{2}-\mathrm{H}_{2} \mathrm{BDC}$. However, as can be seen in Figure 1, in this case the only crystalline phase detected by PXRD characterization in the biocatalysts Lip@ $\mathrm{NH}_{2}-\mathrm{MIL}-53$ (Al) was $\mathrm{NH}_{2}-\mathrm{MIL}-53(\mathrm{Al})$. A lower resolution in the PXRD pattern of the biocatalysts in comparison with that of the enzyme-free support is presumably due to the "dilution" of the crystalline phase of the MOF support in the biocatalyst enzyme@support. No trace of crystallized protonated linker $\mathrm{NH}_{2}-\mathrm{H}_{2} \mathrm{BDC}$ was detected by PXRD at any synthesis time irrespectively of the deprotonating agent used (Figure 1). Although the most intense reflections of the XRD pattern of $\mathrm{NH}_{2}-\mathrm{H}_{2} \mathrm{BDC}$ are close to certain reflections of $\mathrm{NH}_{2}$-MIL-53(Al), the presence of the former is quite evident in the diffractogram when both phases coexist [21]. However, it is worth noting that in the case of using $\mathrm{NaOH}$ as a deprotonating agent, the greater the synthesis time, the sharper the intensity of the signal peaks is obtained for the PXRD pattern, obtaining the maximum intensity after $24 \mathrm{~h}$ of synthesis (Lip@NaOH-24h). Consequently, among all the tested synthesis times, $24 \mathrm{~h}$ was the time that the system took to rearrange itself to accommodate the greatest amount of crystallinity. This behaviour neither was replicated with TEA, nor with $\mathrm{NH}_{4} \mathrm{OH}$ deprotonating agents.

This difference in PXRD results indicate that the enzymes play an active role in the formation of the biocatalysts. The higher proportion of basic amino-acids groups in lipase (isoelectric point of 6.0) than in $\beta$-glucosidase (isoelectric point of 4.3) could avoid the precipitation of the 2-amino-terephthalic acid, which would tend to be soluble. It must be noted that in the absence of any enzyme, the co-precipitation of the MOF X-MIL-53(Al) material and the corresponding linker is the most common scenario with short reaction times [29].

Since the enzyme immobilization occurs within/onto the MOF phase and not on the protonated linker [21], a high percentage of immobilized lipase was reached from the first moment of the synthesis (approx. $1 \mathrm{~h}$ ). The compromise between enzyme immobilization efficiency and the specific enzymatic activity, which severely increases and decreases respectively with synthesis time for in situ immobilization of $\beta$-glucosidase [21], is not found in the case of lipase immobilization.

\subsection{Post-Synthesis Immobilization of Lipase on $\mathrm{NH}_{2}-\mathrm{MIL}-53(\mathrm{Al})$ and MIL-53(Al) Materials}

A potential advantage of the enzyme immobilization over these nanocrystalline sustainable MOF supports is that, apart from the in situ approach, the post-synthesis (two-step) methodology can be investigated in parallel. The comparison between both methodologies can provide valuable information about (i) the chemical affinity between the external surface area of the MOF and the enzyme, (ii) the accessibility of the enzymes to the pores, (iii) the reason behind the possible enzyme leaching, and (iv) the potential to directly compare and rate both approaches in terms of catalytic and specific activities of CaLB lipase.

Unlike the in situ approach, the post-synthesis strategy failed to attain lipase immobilization at a suitable level. Attempts to immobilize CaLB lipase on previously synthesized $\mathrm{NH}_{2}-\mathrm{MIL}-53(\mathrm{Al})$ and MIL-53(Al) supports were unsuccessful. Immobilization yields were not only negligible but also hard to reproduce.

Their respective catalytic activities in $p$-nitrophenyl acetate ( $p$-NPA) hydrolysis were: 4.85 units per gram $\left(\mathrm{U}^{-} \mathrm{g}^{-1}\right.$ ) for Lip\#NH $\mathrm{N}_{2}$-MIL-53(Al) and $7.19 \mathrm{U} \cdot \mathrm{g}^{-1}$ for Lip\#MIL-53(Al), which corresponds to a retained activity relative to the activity of free enzyme of 7.6 and $4.2 \%$, respectively.

The reduced dimensions of the inter-crystalline space, especially in the case of $\mathrm{NH}_{2}-\mathrm{MIL}-53(\mathrm{Al})$ (Figure A2 shows the pore size distribution), is probably the reason behind these poor results. The nanocrystallinity of this sample (Figure A3) could favour the interaction enzyme-MOF but especially when the sample offers accessible mesoporosity. It is proposed that the enzyme can only bind the external surface of the material since diffusion throughout the extremely narrow network might be prevented. This also may serve to explain the low reproducibility of the post-synthesis immobilization yields attained. The size of the particles may vary greatly and therefore the available surface for the enzyme could vary as well. 
Furthermore, it is important to note that the experimental conditions used for the post-synthesis approach have been optimized to retain enzymatic activity, thus enabling catalytic activity to be measured despite the low enzyme loading of the resultant biocatalysts. In comparison, lipase was in situ immobilized under conditions designed for the formation of the MOF material. Therefore, it is presumable that there is still much room to improve the experimental conditions in order to optimize the specific activity in the in situ strategy.

\subsection{Certifying the Presence of the Enzyme in the Biocatalysts}

Apart from the evidence inferred by the catalytic activity tests performed, the presence of the enzyme lipase CaLB on the biocatalysts was also studied by different physico-chemical and biological characterization techniques. Table 2 shows the results of the chemical analyses of the organic elements $\mathrm{C}, \mathrm{H}, \mathrm{N}$, and $\mathrm{S}$.

Table 2. Elemental analysis (in wt $\%$ ) of the enzyme-free MOF material ( $\mathrm{NH}_{2}-\mathrm{MIL}-53(\mathrm{Al})-\mathrm{NaOH}-24 \mathrm{~h}$ ), CaLB lipase extract, and in situ biocatalysts Lip@ $\mathrm{NH}_{2}-\mathrm{MIL}-53(\mathrm{Al})-\mathrm{DA}-x$ synthesized with different deprotonating agents $\mathrm{DA}(\mathrm{NaOH}, \mathrm{TEA}$, or $\mathrm{NH} 4 \mathrm{OH})$ and varying synthesis times $(x$, from 1 to $24 \mathrm{~h}$ ).

\begin{tabular}{|c|c|c|c|c|}
\hline Sample & $\% \mathrm{C}$ & $\% \mathrm{H}$ & $\% \mathbf{N}$ & $\% \mathrm{~S}$ \\
\hline $\mathrm{NH}_{2}$-MIL-53(Al)-NaOH-24 h & 25.8 & 4.7 & 11.7 & 0.00 \\
\hline CaLB lipase extract $\left(5.9 \mathrm{mg} \cdot \mathrm{mL}^{-1}\right)$ & 24.0 & 7.8 & 0.3 & 0.04 \\
\hline Lip@NH & 28.3 & 5.6 & 5.0 & 0.03 \\
\hline Lip@NH - MIL-53(Al)-NaOH-3 h & 27.9 & 4.9 & 4.9 & 0.05 \\
\hline Lip@NH2-MIL-53(Al)-TEA-3 h & 33.1 & 5.9 & 5.8 & 0.03 \\
\hline Lip@NH 2 -MIL-53(Al)-TEA-24 h & 33.6 & 5.0 & 6.0 & 0.05 \\
\hline Lip@NH ${ }_{2}-\mathrm{MIL}-53(\mathrm{Al})-\mathrm{NH}_{4} \mathrm{OH}-3 \mathrm{~h}$ & 21.3 & 6.4 & 4.7 & 0.02 \\
\hline Lip@NH ${ }_{2}-\mathrm{MIL}-53(\mathrm{Al})-\mathrm{NH}_{4} \mathrm{OH}-24 \mathrm{~h}$ & 33.4 & 4.8 & 7.3 & 0.04 \\
\hline
\end{tabular}

Although elemental analysis is a quantitative technique, since the linker of the MOF also contains elements $\mathrm{C}, \mathrm{N}$, and $\mathrm{H}$, this technique cannot be used as definitive proof of the presence of the enzyme within the MOF. Since sulphur (S) is not present in the MOF but is present in the enzyme, this could potentially be used as a means of confirming the enzyme loading of the MOF material. All the biocatalysts contain a certain amount of $\mathrm{S}$ except that of the enzyme-free $\mathrm{NH}_{2}-\mathrm{MIL}-53(\mathrm{Al})$, which indeed suggests the presence of lipase in every solid biocatalyst. In addition, the $S$ content generally increases with the synthesis time for a given deprotonating agent, which is in good agreement with the trend to increase the enzyme immobilization shown in Table 1.

The biocatalysts were also characterized by thermogravimetric analysis (TGA) in order to try to identify the enzymes taking advantage of its different thermal stability compared with the rest of components of the biocatalyst. In this regard, Figure 2 shows the TGA curves of all Lip@ $\mathrm{NH}_{2}-\mathrm{MIL}-53(\mathrm{Al})$ samples included in Table 1. The TGA curves of the enzyme-free MOF and the free lipase CaLB have been included to aid in the interpretation of the mass losses. Both biocatalysts prepared using TEA as a deprotonating agent under different synthesis times, have practically the same TGA curves. Under $3 \mathrm{~h}$ of synthesis time the three biocatalysts (one with $\mathrm{NaOH}$, one with TEA, and one with $\mathrm{NH}_{4} \mathrm{OH}$ ) present an abrupt weight loss near $250^{\circ} \mathrm{C}$, which might be attributed to the presence of the enzyme. The magnitude of these mass losses is higher than $10 \%$, much higher than the immobilized enzyme (Table 1), suggesting that this mass loss may be ascribed to the enzyme molecules encapsulated by the MOF as well as the enzyme located on the surface of the MOF. This behaviour has already been detected in other in situ immobilizations of enzymes with different MOF materials [23]. The TGA curves of the biocatalysts prepared at longer times $(24 \mathrm{~h})$ with any of these three deprotonating agents exhibit similar mass losses but not as noticeable, and they occur at higher temperatures $\left(>300^{\circ} \mathrm{C}\right)$ which might hint at a higher lipase encapsulation in the MOF compared to on the surface. 

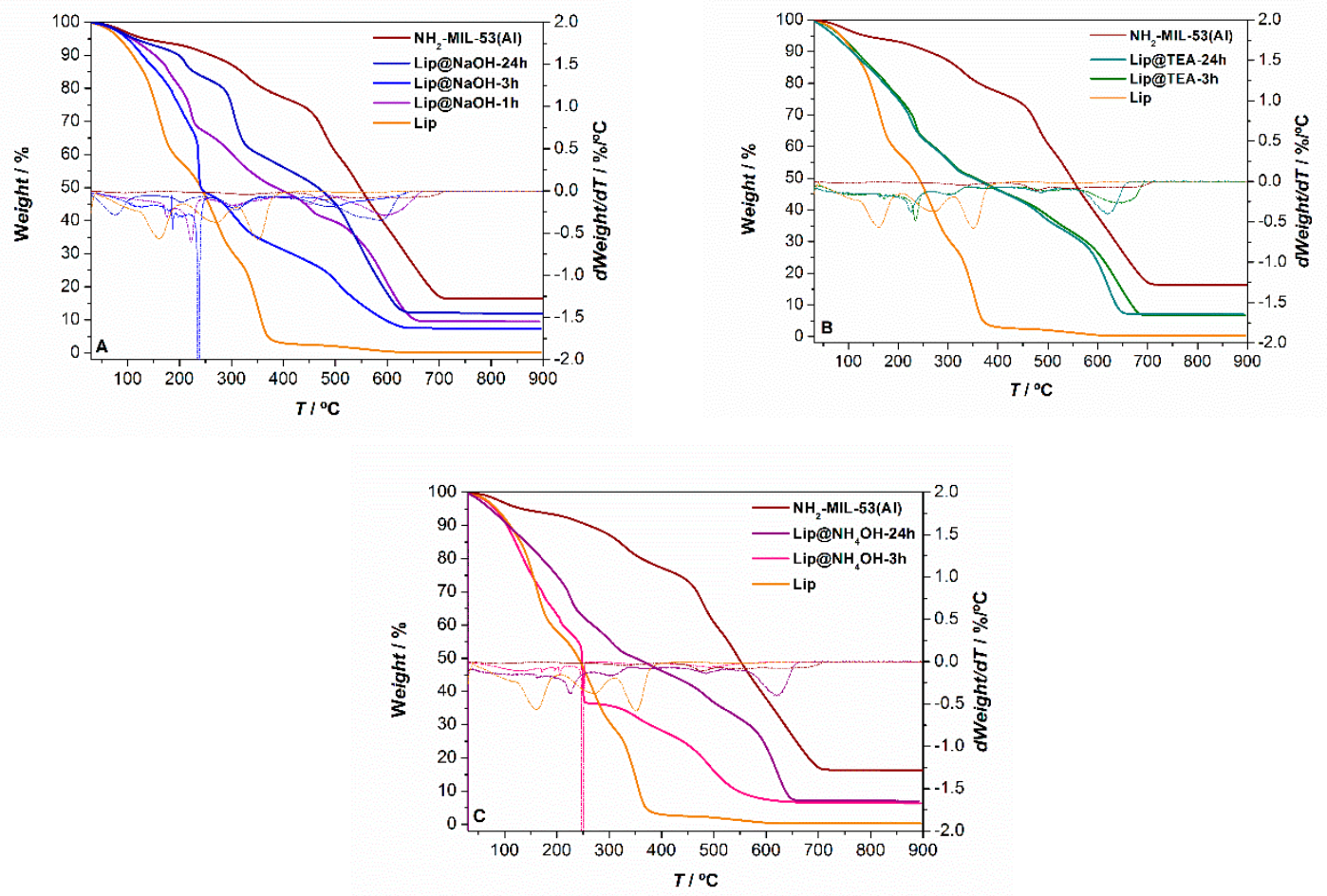

Figure 2. Thermogravimetric analysis-TGA-(left Y-axis, solid lines) and differential thermogravimetric_DTG—curves (right Y-axis, dashed lines) curves of: (A) The $\mathrm{NH}_{2}-\mathrm{MIL}-53(\mathrm{Al})-\mathrm{NaOH}-24 \mathrm{~h}$ material (wine lines), the lipase extract (orange), and biocatalysts Lip@ $\mathrm{NH}_{2}-\mathrm{MIL}-53(\mathrm{Al})-\mathrm{NaOH}-x$ after $1 \mathrm{~h}$ (violet), $3 \mathrm{~h}$ (blue), and $24 \mathrm{~h}$ (cyan) of preparation; (B) of the $\mathrm{NH}_{2}-\mathrm{MIL}-53(\mathrm{Al})-\mathrm{NaOH}-24 \mathrm{~h}$ material (wine), the lipase extract (orange), and biocatalysts Lip@ $\mathrm{NH}_{2}-\mathrm{MIL}-53(\mathrm{Al})-\mathrm{TEA}-x$ after $3 \mathrm{~h}$ (olive) and $24 \mathrm{~h}$ (dark cyan) of preparation; and (C) of the $\mathrm{NH}_{2}-\mathrm{MIL}-53(\mathrm{Al})-\mathrm{NaOH}-24 \mathrm{~h}$ material (wine), the lipase extract (orange), and biocatalysts Lip@ $\mathrm{NH}_{2}-\mathrm{MIL}-53(\mathrm{Al})-\mathrm{NH}_{4} \mathrm{OH}-x$ after $3 \mathrm{~h}$ (pink) and $24 \mathrm{~h}$ (purple) of preparation.

In another effort to detect the presence and/or absence of the enzyme in the biocatalysts, the SDS-PAGE electrophoresis gel technique was employed [43]. In this sense, Figure 3 shows the image of the lipase CaLB extract and the in situ and post-synthesis lipase-containing biocatalysts. All the biocatalysts gave a signal in the electrophoresis gel between 31 and $45 \mathrm{kDa}$, which was attributed to the enzyme lipase CaLB, whose molecular weight is $33.5 \mathrm{kDa}$. Thin bands in lanes 7 and 8 in Figure $3 \mathrm{~A}$ show the large difference in the immobilization yields of the post-synthesis biocatalysts. In situ biocatalysts Lip@ $\mathrm{NH}_{2}-\mathrm{MIL}-53(\mathrm{Al})$ produced much wider bands, due to the higher enzyme loading.

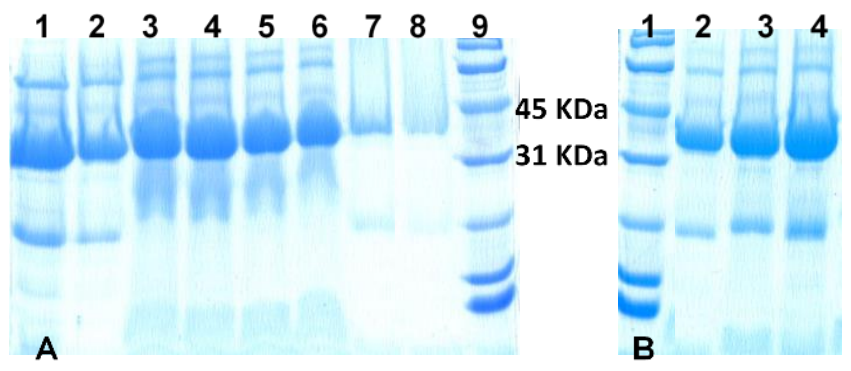

Figure 3. (A) 12\% SDS-PAGE electrophoresis gel of (from right to left): (1) CaLB lipase extract, biocatalysts, (2) Lip@NH 2 -MIL-53(Al)-NaOH-1 h, (3) Lip@NH $2-\mathrm{MIL}-53(\mathrm{Al})-\mathrm{NaOH}-3 \mathrm{~h}$, (4) Lip@NH $2-\mathrm{MIL}-53(\mathrm{Al})-\mathrm{NaOH}-24$ h, (5) Lip@NH 2 -MIL-53(Al)-TEA-3 h, (6) Lip@NH2-MIL-53(Al)-TEA-24 h, (7) Lip\#MIL-53(Al)-NaOH-3 h, (8) Lip\#NH 2 -MIL-53(Al)-NaOH-3 h, (9) a protein marker. (B) 12\% SDS-PAGE electrophoresis gel of (from right to left): (1) A protein marker, (2) Lip@ $\mathrm{NH}_{2}-\mathrm{MIL}-53(\mathrm{Al})-\mathrm{NH}_{4} \mathrm{OH}-3 \mathrm{~h}$, (3) Lip@ $\mathrm{NH}_{2}-\mathrm{MIL}-53(\mathrm{Al})-\mathrm{NH}_{4} \mathrm{OH}-24 \mathrm{~h}$, (4) CaLB lipase extract. 


\subsection{Enzyme Leaching}

To ascertain the amount of enzyme immobilized in the MOF, the enzyme concentration initially present as identified by the Bradford method [40] was subtracted from the residual concentration of enzyme after filtering (Bradford method, Table 1). The resultant biocatalysts were tested in the leaching experiment.

Enzyme leaching is a key parameter in the solid biocatalysts formed by the immobilization of enzymes. In this work, the biocatalysts (in situ and post-synthesis) were suspended in a solution under conditions designed for lipase leaching, which were even more aggressive than the conditions used under the tested catalytic reaction. Figure 4 shows the enzyme leaching during $48 \mathrm{~h}$ for the main catalysts prepared by either methodology.

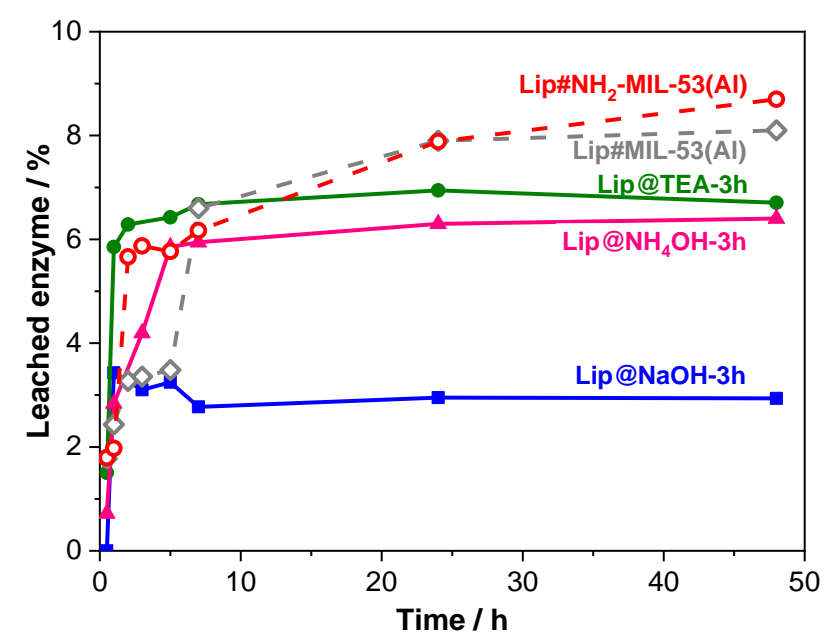

Figure 4. Percentage of lipase leaching along the time for different post-synthesis (dashed lines, empty symbols) and in situ (solid lines, full symbols) biocatalysts.

The most remarkable feature of Figure 4 is that the leaching is below $7 \%$ of the in situ immobilized lipase. The total enzyme leaching of these biocatalysts Lip@ $\mathrm{NH}_{2}-\mathrm{MIL}-53(\mathrm{Al})$ is produced in the first $5 \mathrm{~h}$. After this time, no more enzyme is released in any of these biocatalysts indicating that the remaining enzyme is strongly retained inside the crystalline network of the MOFs. The initial desorption may be due to the presence of weakly (physically) adsorbed enzyme molecules, which are easily released from their associated support.

It is particularly remarkable that the biocatalyst Lip@ $\mathrm{NH}_{2}-\mathrm{MIL}-53(\mathrm{Al})$ prepared by the in situ methodology using $\mathrm{NaOH}$ as a deprotonating agent $(1 \mathrm{~h})$, scarcely lost $3 \%$ of the initially retained lipase providing an additional advantage to this biocatalyst.

The shape of the curves corresponding to lipase leaching of the post-synthesis Lip\#NH $\mathrm{N}_{2}-\mathrm{MIL}-53(\mathrm{Al})$ is different. After an initial fast enzyme desorption, similar to that exhibited by the in situ method, the enzyme released does not stop but continues increasing. This indicates that the enzyme molecules may not be retained within the MOF network.

\section{Materials and Methods}

\subsection{Reagents and Chemicals}

The organic linkers 2-aminoterephthalic acid $\left(\mathrm{NH}_{2}-\mathrm{H}_{2} \mathrm{BDC}, 98 \%\right)$ and terephthalic acid $\left(\mathrm{H}_{2} \mathrm{BDC}\right.$, 99\%) was purchased from Sigma-Aldrich. The metallic precursor aluminum nitrate nonahydrate $\left(\mathrm{Al}\left(\mathrm{NO}_{3}\right)_{3} \cdot 9 \mathrm{H}_{2} \mathrm{O}, \geq 98 \%\right)$ was acquired from Sigma-Aldrich. Sodium hydroxide $(\geq 98 \%)$ and ammonia $(29 \%)$ were from Panreac whereas triethylamine $(\geq 99 \%)$ was acquired from Sigma-Aldrich. 
The extract of soluble CaLB L Lipase (Lipozyme CaLB L) from Candida sp. recombinant, expressed in Aspergillus niger was kindly provided by Novozymes. Enzyme substrates 4-nitrophenyl-acetate ( $p$-NPA, $\geq 98 \%$ ) and tributyrin (TB) were purchased from Sigma-Aldrich (Madrid, Spain).

Sodium hydroxide $(\mathrm{NaOH}, \geq 98 \%)$, acetic acid $(99 \%)$, and di-sodium hydrogen phosphate dihydrate were purchased from Panreac. Sodium acetate anhydrous $(>99 \%)$ was acquired from Scharlab. Phosphoric acid ( $85 \%$ ) and citric acid was purchased from Sigma-Aldrich. Tri-sodium citrate dehydrate was from Analyticals Carlo Erba (Cornaredo, Milan, Italy).

Commercial protein standard bovine serum albumin (BSA) purchased from Sigma-Aldrich along with Coomassie Brilliant Blue R-250 staining solution acquired from Bio-Rad were used for determination of protein concentration employing the Bradford assay determination method.

The employed reagents for electrophoresis (SDS-PAGE) were: Mercaptoethanol (>99\%) purchased from Sigma-Aldrich; tetrabromophenolsulfonphthalein or bromophenol blue indicator and glycerol (>99\%) provided by Sigma; tris(hydroxymethyl) aminomethane (Tris base) purchased from Fluka Analytical; sodium dodecyl sulfate (SDS), ammonium persulfate (APS), $\mathrm{N}, \mathrm{N}_{,} \mathrm{N}^{\prime}, \mathrm{N}^{\prime}$-tetramethylethylenediamine (TEMED), 40\% acrylamide/bis solution, 10x Tris base/glycine/SDS buffer and bio-safeTM coomasie G-250 stain all purchased from Bio-Rad, and finally the SDS molecular weight standard was provided by Bio-Rad.

All reagents and solvents were of analytical grade, and were used as received without any further purification. All solutions were prepared using deionized water obtained from a Milli-Q Plus/Millipore purification system $(18 \mathrm{M} \Omega \cdot \mathrm{cm})$.

\subsection{Characterization of the Supports and Biocatalysts}

Powder X-ray diffraction (PXRD) patterns were acquired with a X'PERT Pro PANalytical diffractometer using the $\mathrm{Cu}-\mathrm{K} \alpha$ radiation $(\lambda=1.5406 \AA)$. The data were registered with a two theta step size $0.04^{\circ}$ from 4 to $90^{\circ}$ and accumulation time of $20 \mathrm{~s}$.

Adsorption-desorption isotherms of the samples were measured on ASAP 2020 or ASAP 2420 devices at $-196{ }^{\circ} \mathrm{C}$ using nitrogen as adsorption gas. The samples were outgassed at $70{ }^{\circ} \mathrm{C}$ for $16 \mathrm{~h}$ prior to analysis. Pore diameter distributions were determined from the adsorption branch of the nitrogen isotherms using the BJH (Barrett-Joyner-Halenda) method.

Quantitative determinations of nitrogen and sulphur contents belonging to the enzymes extract and biocatalysts were performed using a LECO CHNS-932 Elemental Analyser with an AD-4 autobalance.

Thermogravimetric analyses (TGA) were carried out using a Perkin-Elmer TGA 7 instrument. Samples were heated in an air flow at atmospheric pressure from 25 to $900{ }^{\circ} \mathrm{C}$ at a heating rate of $20^{\circ} \mathrm{C} \cdot \mathrm{min}^{-1}$.

The particle size and morphologies were examined by using a scanning electron microscope (SEM). Images were collected using a XL30S FEG XL SERIES Philips microscope with ECON IV detector. The samples were prepared on a double-sided graphite adhesive tape mounted on the sample holder, and afterwards were metalized by sputtering with a coating of ultra-thin chromium layer before being inserted into the microscope.

\subsection{In Situ Immobilization: Lip@NH $-M I L-53(A l)$ Biocatalysts}

The $\mathrm{NH}_{2}-\mathrm{MIL}-53(\mathrm{Al}) \mathrm{MOF}$ material was prepared in water at room temperature to compare with the in situ biocatalysts (all together in one-pot synthesis) lipase immobilization methods using three different deprotonating agents $\left(\mathrm{NaOH}, \mathrm{TEA}\right.$, and $\left.\mathrm{NH}_{4} \mathrm{OH}\right)$.

The preparation method of the biocatalysts Lip@ $\mathrm{NH}_{2}-\mathrm{MIL}-53(\mathrm{Al})$ is similar to the one described for the enzyme-free $\mathrm{NH}_{2}$-MIL-53(Al) MOF material employing room temperature and water [20,21]. Slight differences are due to the incorporation of the enzyme extract, in which part of the water quantity used within the organic linker solution was substituted by the enzyme extract solution, and a modification of the addition order was employed to prevent exposure of the enzymes to extreme $\mathrm{pH}$ values. 
In a typical synthesis procedure, two clear aqueous solutions were separately prepared (Scheme 1). The organic linker solution (solution 1 ) was prepared by dissolving $0.482 \mathrm{~g}$ of 2 -aminoterephtalic acid $\left(\mathrm{NH}_{2}-\mathrm{H}_{2} \mathrm{BDC}\right)$ in $13.2 \mathrm{~g}$ deionized water, assisted by one of the following three deprotonating agents (DA): Sodium hydroxide solution ( $\mathrm{NaOH} 1.04 \mathrm{M}, 5.30 \mathrm{~g}$ ), triethylamine (TEA, $0.539 \mathrm{~g}$ ), or ammonium hydroxide solution $\left(\mathrm{NH}_{4} \mathrm{OH} 29 \mathrm{wt} \%, 0.644 \mathrm{~g}\right)$. The amount of water was adjusted by taking into account the water content contained in the deprotonating agent source for the case of $\mathrm{NaOH}$ and $\mathrm{NH}_{4} \mathrm{OH}$. In the absence of these agents, the linker is not soluble, whereas in the presence of any of them the mixture becomes a clear solution after some time (ca. $10 \mathrm{~min} \mathrm{NaOH}, 3 \mathrm{~h} \mathrm{TEA}$ and $\mathrm{NH}_{4} \mathrm{OH}$ ). The resultant $\mathrm{pH}$ value of this solution was near neutral (around 6), and it was higher for stronger bases used as deprotonating agents.

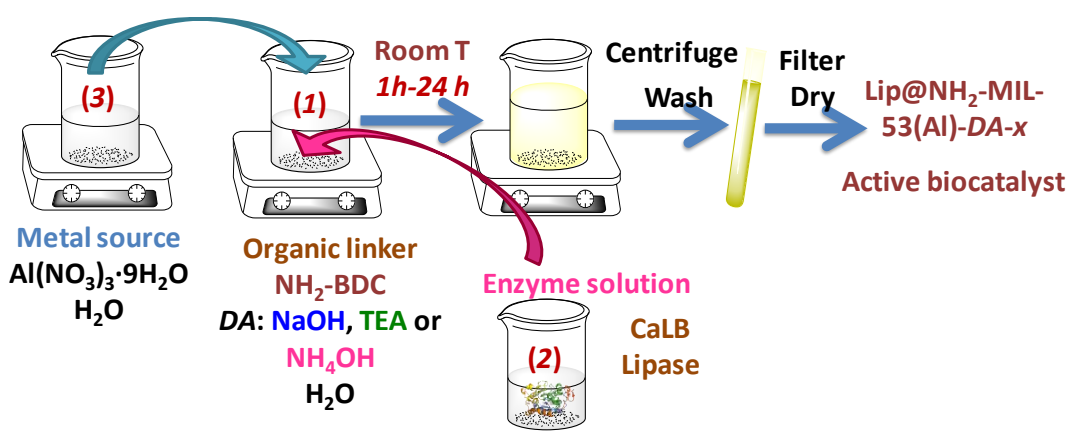

Scheme 1. Procedure for the preparation of Lip@ $\mathrm{NH}_{2}-\mathrm{MIL}-53(\mathrm{Al})-\mathrm{DA}-x$ biocatalysts by the in situ approach (identified by using the @ symbol), where DA or deprotonating agents could be $\mathrm{NaOH}, \mathrm{TEA}$ or $\mathrm{NH}_{4} \mathrm{OH}$, and $x$ is the particular synthesis time employed in every synthesis biocatalyst sample.

The enzymatic solution (solution 2) was formed by $5 \mathrm{~mL}$ of a CaLB lipase extract with a concentration of $5.9 \mathrm{mg}$ protein $\cdot \mathrm{mL}^{-1}$ (measured by the Bradford assay). The metallic source solution (solution 3) was prepared by dissolving $2.0 \mathrm{~g}$ of $\mathrm{Al}\left(\mathrm{NO}_{3}\right)_{3} \cdot 9 \mathrm{H}_{2} \mathrm{O}$ in $6.0 \mathrm{~g}$ Milli-Q grade water reaching a $\mathrm{pH}$ around 2.0.

The lipase extract (solution 2) was added over the linker solution (solution 1), inducing a slight $\mathrm{pH}$ decrease (ca. 0.5 units) for all mixtures. The metal solution (solution 3 ) was gently added dropwise into the linker-enzyme solution mixture under slow magnetic stirring in order to prevent $\mathrm{pH}$ variations. This procedure resulted in an instant appearance of a yellowish precipitate, which is considered to be the solid biocatalyst MOF material. The $\mathrm{pH}$ of the resultant suspension was acidic, slightly above 3 . This addition order was selected to minimize enzyme exposure and subsequent denaturing and/or deactivation in extreme acidic media provided by solution 3 .

The resultant suspension was maintained under permanent stirring at $25^{\circ} \mathrm{C}$ for different reaction times. The obtained solid was then vacuum filtered, washed with Milli-Q grade water and finally dried under a continuous nitrogen flow. The resultant biocatalysts were weighed, gently ground to a powder, and stored at $4{ }^{\circ} \mathrm{C}$. The solid biocatalysts were named as Lip@NH $\mathrm{NH}_{2}-\mathrm{ML}-53(\mathrm{Al})-\mathrm{DA}-x$, where DA can be $\mathrm{NaOH}, \mathrm{TEA}$ or $\mathrm{NH}_{4} \mathrm{OH}$, and $x$ is the synthesis time employed in each sample $(1,3$, and $24 \mathrm{~h}$ for Lip@ $\mathrm{NH}_{2}-\mathrm{MIL}-53(\mathrm{Al})-\mathrm{NaOH}$ biocatalysts, as well as 3 and 24 h for Lip@NH $\mathrm{NH}_{2}-\mathrm{MIL}-53(\mathrm{Al})-\mathrm{TEA}$ and Lip@ $\mathrm{NH}_{2}-\mathrm{MIL}-53(\mathrm{Al})-\mathrm{NH}_{4} \mathrm{OH}$ biocatalysts, respectively). During the process of lipase immobilization, aliquots were withdrawn every half an hour, and the enzymatic activity of the blank, suspension and supernatant (after separating it by centrifugation) were assayed spectrophotometrically by the hydrolysis of $p$-nitrophenyl acetate ( $p$-NPA) conducted by lipase. 


\subsection{Post-Synthesis Immobilization: Lip\#MIL-53(Al) and Lip\#NH ${ }_{2}-M I L-53(A l)$ Biocatalysts}

Enzyme-free MOF materials, MIL-53(Al) and $\mathrm{NH}_{2}-\mathrm{MIL}-53(\mathrm{Al})$ were prepared in water at room temperature according to the methods described [20,21]. These MOF materials were used as supports for the post-synthesis immobilization of lipase (immobilization after the synthesis of the material) (Scheme 2).

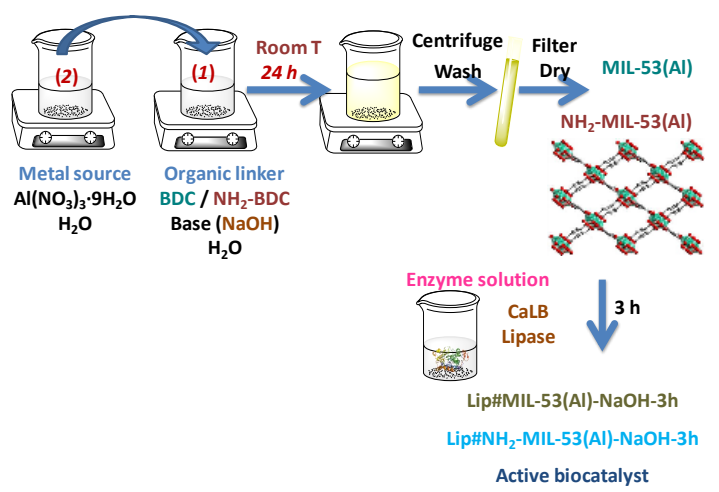

Scheme 2. Procedure for the preparation of Lip\#MIL-53(Al) and $\mathrm{Lip \# NH}_{2}-\mathrm{MIL}-53(\mathrm{Al})$ biocatalysts by the post-synthesis approach (symbolized by \#).

Post-synthesis immobilization of lipase on either of the two MOF materials (MIL-53(Al), $\mathrm{NH}_{2}$-MIL-53(Al)) was carried out by suspending $50.0 \mathrm{mg}$ of the MOF material in $10 \mathrm{~mL}$ of lipase aqueous solution $\left(0.25 \mathrm{mg} \cdot \mathrm{mL}^{-1}\right)$ in $50 \mathrm{mM}$ acetic acid/sodium acetate buffer at $\mathrm{pH} 5.0$ (Scheme 2). The suspension was kept under mild stirring conditions for $3 \mathrm{~h}$ (no further enzyme molecules were immobilized after $3 \mathrm{~h}$ ). During the process of lipase immobilization, aliquots were withdrawn following the same sequence as in the in situ procedure. The decrease in activity of the supernatant to a minimum and constant value indicated the end of the immobilization process. The amount of enzyme immobilized onto the support was calculated by two methods: The difference between the respective activities of the blank or suspension and the supernatant. The second method measured the protein content of the supernatant before and after the immobilization process by the Bradford assay [40]. The suspension was then vacuum filtered and the resultant solid biocatalysts were washed with the same acetic acid/sodium acetate buffer used for immobilization. No protein was detected in the washing residues (measured by the said Bradford assay). The solid samples were then dried under a vacuum and were stored at $4{ }^{\circ} \mathrm{C}$ for further analysis.

\subsection{Determination of Enzymatic Activity of the Lipase Extract and Heterogeneous Lipase-Containing Biocatalysts}

Hydrolysis of $p$-NPA was used as a routine test for measuring spectrophotometrically the nonspecific esterase activity during the process of lipase immobilization and to calculate the enzyme loading $\left(\mathrm{mg} \cdot \mathrm{g}^{-1}\right)$ [36]. The activity tests were conducted in triplicate and the average value was calculated for the initial enzyme solution (or blank solution), for the suspension solution (heterogeneous biocatalyst + enzyme solution), and for the supernatant (after centrifugation of the suspension solution). Such spectrophotometrically measurements were conducted in a Diode array UV-Vis spectrophotometer (Agilent 8453) equipped with a constant stirring device and temperature controller. The reaction mixture within the sample cuvette contained $1.9 \mathrm{~mL}$ of a previously prepared $0.4 \mathrm{mM} p$-NPA aqueous solution (pH 7.0). A $50 \mu \mathrm{L}$ aliquote of the enzyme solution (blank, suspension or supernatant) was then added in the reaction mixture, and afterwards the increase ratio of absorbance per minute due to the release of $p$-nitrophenol product coming from $p$-NPA hydrolysis was continuously monitored during $5 \mathrm{~min}$ at $348 \mathrm{~nm}$ and $25^{\circ} \mathrm{C}$. The molar absorption coefficient was taken as $\varepsilon_{348} \mathrm{~nm}=5150 \mathrm{M}^{-1} \cdot \mathrm{cm}^{-1}$. A unit of lipase activity $(\mathrm{U})$ was defined as the amount of enzyme required to hydrolize $1 \mu \mathrm{mol}$ of $p$-NPA per minute at $25^{\circ} \mathrm{C}$. 
In order to determine the catalytic activity of the Lipase (Lip) heterogeneous biocatalyst, tributyrin hydrolysis was used as an activity test [36] (Scheme 3). This method is even more specific than the hydrolysis of $p$-NPA. This assay measures the lipase activity by butyric acid release, and it was monitored titrimetrically in a DL-50 pH-state Mettler Toledo, using a $100 \mathrm{mM}$ sodium hydroxide aqueous solution. Then, $48.5 \mathrm{~mL}$ of potassium phosphate buffer $(10 \mathrm{mM}, \mathrm{pH} 7.0)$ were incubated in a thermostated vessel at $25^{\circ} \mathrm{C}$ and under stirring. After that, $1.47 \mathrm{~mL}$ of tributyrin was added and the $\mathrm{pH}$-state was stated to keep the $\mathrm{pH}$ at 7.0. When the $\mathrm{pH}$ stabilized, $10 \mathrm{mg}$ of the catalyst were added and the consumption of $\mathrm{NaOH}$ was determined. One lipase unit corresponds to consumption of $1 \mu \mathrm{mol} \mathrm{NaOH} / \mathrm{min}$. All measurements were performed in triplicate and their average rate value was taken for plotting and discussion.

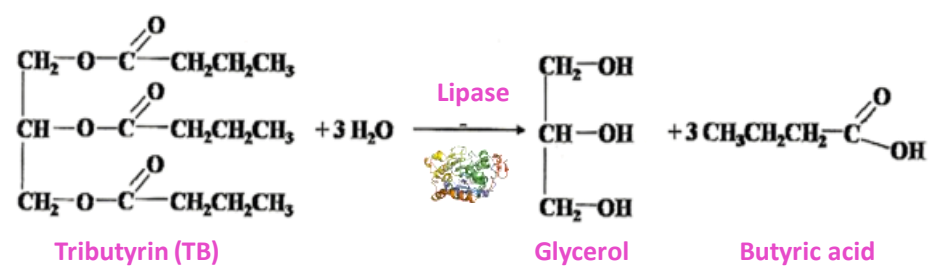

Scheme 3. Hydrolysis reaction of tributyrin (TB) to glycerol and butyric acid conducted by CALB lipase [36].

\subsection{Leaching Tests}

In order to infer the resistance of the enzyme to leach from the support, a leaching test was performed. It consisted of subjecting the solid biocatalysts to conditions that presumably favoured the enzyme release by re-suspending the biocatalyst in a high dilution and low ionic strength buffer solution. Consequently, the biocatalysts were incubated along the time in a $50 \mathrm{mM}$ phosphoric acid/trisodium citrate buffer solution at $\mathrm{pH} 5.0$ with a content of $1.25 \mathrm{mg}$ of solid per $\mathrm{mL}$ of buffer solution. These incubation periods were $0.5,1,2,3,5,7,24$, and $48 \mathrm{~h}$. Enzyme leaching was calculated by monitoring the appearance of protein in the supernatant employing the Bradford assay [40].

\subsection{Electrophoresis Tests}

In order to indirectly detect in a qualitative way the presence of lipase enzyme inside the solid supports after $48 \mathrm{~h}$ of leaching tests by means of SDS-PAGE electrophoresis, and provided the fact that solid samples are not suitable for this technique, first of all an enzyme denaturalization was conducted by employing a rupture buffer solution obtained according to Laemmli protocol [41] containing: $240 \mu \mathrm{L}$ sodium dodecyl sulphate $20 \%, 500 \mu \mathrm{L}$ Tris/HCl buffer $2.5 \mathrm{M} \mathrm{pH} 6.8,1960 \mu \mathrm{L}$ Milli-Q water, $2000 \mu \mathrm{L}$ glycerol, $800 \mu \mathrm{L}$ bromophenol blue $0.05 \%$, and $1100 \mu \mathrm{L}$ mercaptoethanol, and then boiled for $10 \mathrm{~min}$. This denaturalization aimed to transform the enzyme tertiary structure (including the split of disulphide bonds) into a random coil chain with the sole purpose of allowing it to leak from the solid framework. As a result, a solution was obtained in which after centrifugation a supernatant could be distinguished presumably containing said protein chains. Afterwards, the withdrawal of this supernatant could be easily performed by centrifugation and then analyzed using a $12 \%$ SDS-PAGE electrophoresis gel previously prepared in-house.

\section{Conclusions}

The in situ immobilization of the enzyme lipase CaLB within the MOF $\mathrm{NH}_{2}-\mathrm{MIL}-53(\mathrm{Al})$ support prepared at room temperature and in an aqueous solution has proven to be an efficient and successful approach. This one-step method is quick, easy to prepare, inexpensive, and efficient when immobilizing almost all the enzyme present in the media, as more than $86 \%$ of the enzyme present in the synthesis media is encapsulated. The resultant biocatalyst obtained in this work is quite active in the tested catalytic reaction (i.e., the biocatalyst Lip@NaOH-3h retains $27 \%$ of the activity), and was capable of 
rendering a low lipase enzyme leaching under the tested conditions (around only $2.5 \%$ of enzyme was leached from the biocatalyst Lip@NaOH-3h). The key advantage of in situ immobilization with lipase CaLB against $\beta$-glucosidase [21] revolves around the fact that, as stated by PXRD, the MOF phase was the only one detected in the lipase-containing biocatalysts. This implies that the method is much more rapid (i.e., when achieving $96 \mathrm{~h}$ of immobilization, CaLB lipase took $21 \mathrm{~h}$ less than $\beta$-glucosidase when using $\mathrm{NaOH}$ as a deprotonating agent), it is almost instantaneous and avoids the exposure of the enzyme to the synthesis media, which is not appropriate for keeping it active (i.e., Lip@NaOH-1h renders the maximum catalytic activity, $1218 \mathrm{U} \cdot \mathrm{g}^{-1}$, for the minimum immobilization time, $1 \mathrm{~h}$ ). On the other hand, the post-synthesis methodology happened to immobilize much lower concentrations of lipase enzyme, and even the amino-functionalized MIL-53(Al) MOF was not efficient enough to promote a strong interaction between the enzyme and the support achieving only $4.85 \mathrm{U} \cdot \mathrm{g}^{-1}$ for Lip\#NH $\mathrm{N}_{2}$-MIL-53(Al).

Author Contributions: Conceptualization, V.G.-P., R.M.B., and M.S.-S.; methodology, V.G.-P., M.B.J., and A.M.; writing - original draft preparation, V.G.-P. and M.S.-S.; writing—review and editing, V.G.-P., A.M., R.M.B., and M.S.-S.; funding acquisition, R.M.B. and M.S.-S. All authors have read and agreed to the published version of the manuscript.

Funding: This work has been funded by the Spanish State Research Agency (Agencia Española de Investigación, AEI) and the European Regional Development Fund (Fondo Europeo de Desarrollo Regional, FEDER) through the Project MAT2016-77496-R (AEI/FEDER, UE). A.M. acknowledges Spanish MINECO for the PhD student contract BES-2017-082077. V.G.P. acknowledges the Irish Research Council under the Government of Ireland Postdoctoral Fellowship - GOIPD/2015/287.

Acknowledgments: The authors thank Ramiro Martínez (Novozymes, Spain) for the CALB lipase extract sample. The authors thank C. I. Bachour Sirerol for critical comments on the manuscript.

Conflicts of Interest: The authors declare no conflict of interest.

\section{Appendix A Extra Figures}

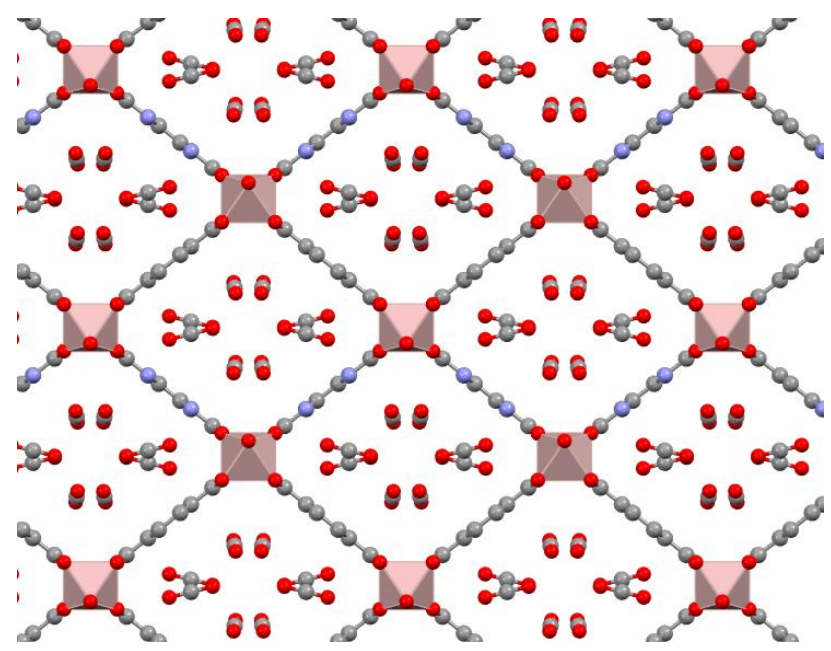

Figure A1. View of the structure of the as-prepared $\mathrm{NH}_{2}-\mathrm{MIL}-53(\mathrm{Al})$ along $a$ axis. Due to the high flexibility of this metal-organic framework (MOF) material, it can adopt different structures. This figure shows the structure known as "as" because it is the unique one used in this work. It is characterized for having the pores occupied by protonated linker molecules $\mathrm{NH}_{2}-\mathrm{H}_{2} \mathrm{BDC}$ (partially represented in the cavities in the Figure). In any case, even when the pores are void, their size (pore diameter below $1 \mathrm{~nm}$ ) is far from being large enough to house the lipase enzyme inside. Color code: $\mathrm{C}$, gray; $\mathrm{O}$, red; $\mathrm{N}$, blue; Al, beige. 


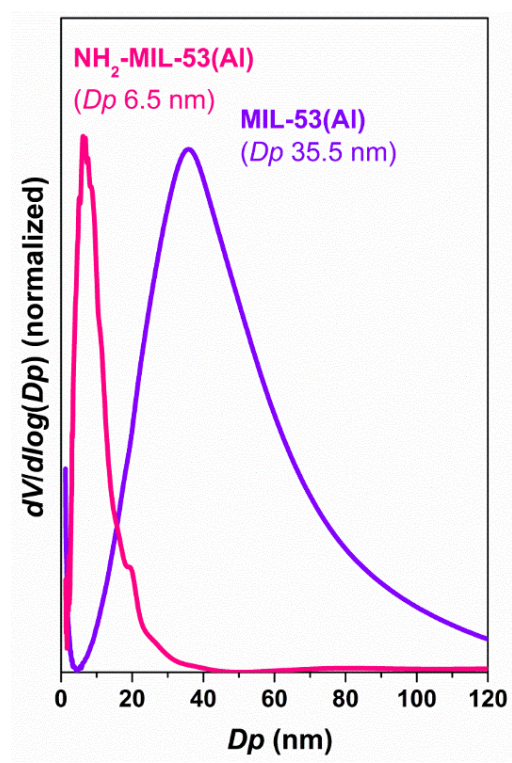

Figure A2. The Barrett-Joyner-Halenda (BJH) pore size distribution (PSD) of $\mathrm{NH}_{2}-\mathrm{MIL}-53(\mathrm{Al})$ and MIL-53(Al) materials arisen from the adsorption branch. Estimated PSD maxima indicated in brackets.

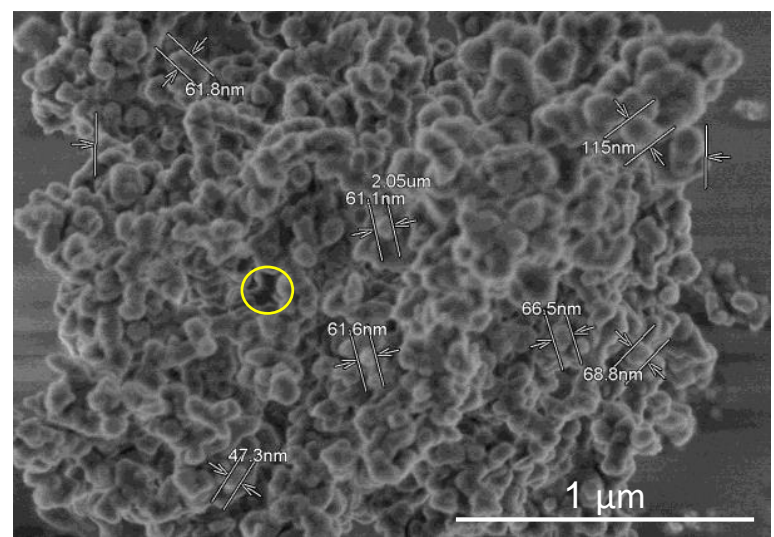

Figure A3. Representative SEM image of $\mathrm{NH}_{2}-\mathrm{MIL}-53(\mathrm{Al})$ material (prepared at room temperature after $24 \mathrm{~h}$ and using $\mathrm{NaOH} 1 \mathrm{M}$ as a deprotonating agent) showing average particle size (i.e., white circle), and intercrystalline mesoporosity in between the particles (i.e., yellow circle).

\section{References}

1. Li, H.; Eddaoudi, M.; O'Keeffe, M.; Yaghi, O.M. Design and Synthesis of an Exceptionally Stable and Highly Porous Metal-Organic Framework. Nature 1999, 402, 276-279. [CrossRef]

2. Eddaoudi, M.; Li, H.; Reineke, T.; Fehr, M.; Kelley, D.; Groy, T.L.; Yaghi, O.M. Design and Synthesis of Metal-Carboxylate Frameworks with Permanent Microporosity. Top. Catal. 1999, 9, 105-111. [CrossRef]

3. Moulton, B.; Zaworotko, M.J. From Molecules to Crystal Engineering: Supramolecular Isomerism and Polymorphism in Network Solids. Chem. Rev. 2001, 101, 1629-1658. [CrossRef] [PubMed]

4. Eddaoudi, M.; Moler, D.B.; Li, H.; Chen, B.; Reineke, T.M.; O'Keeffe, M.; Yaghi, O.M. Modular Chemistry: Secondary Building Units as a Basis for the Design of Highly Porous and Robust Metal-Organic Carboxylate Frameworks. Acc. Chem. Res. 2001, 34, 319-330. [CrossRef] [PubMed]

5. Batten, S.R.; Champness, N.R.; Chen, X.M.; Garcia-Martinez, J.; Kitagawa, S.; Ohrstrom, L.; O'Keeffe, M.; Suh, M.P.; Reedijk, J. Terminology of Metal-Organic Frameworks and Coordination Polymers (IUPAC Recommendations 2013). Pure Appl. Chem. 2013, 85, 1715-1724. [CrossRef]

6. Furukawa, H.; Cordova, K.E.; O'Keeffe, M.; Yaghi, O.M. The Chemistry and Applications of Metal-Organic Frameworks. Science 2013, 341, 1230444. [CrossRef] 
7. Griffin, S.L.; Champness, N.R. A Periodic Table of Metal-Organic Frameworks. Coord. Chem. Rev. 2020, 414, 213295. [CrossRef]

8. Stock, N.; Biswas, S. Synthesis of Metal-Organic Frameworks (MOFs): Routes to Various MOF Topologies, Morphologies, and Composites. Chem. Rev. 2012, 112, 933-969. [CrossRef]

9. Safaei, M.; Foroughi, M.M.; Ebrahimpoor, N.; Jahani, S.; Omidi, A.; Khatami, M. A Review on Metal-Organic Frameworks: Synthesis and Applications. Trends Anal. Chem. 2019, 118, 401-425. [CrossRef]

10. Wu, X.; Hou, M.; Ge, J. Metal-Organic Frameworks and Inorganic Nanoflowers: A Type of Emerging Inorganic Crystal Nanocarrier for Enzyme Immobilization. Catal. Sci. Technol. 2015, 5, 5077-5085. [CrossRef]

11. Mehta, J.; Bhardwaj, N.; Bhardwaj, S.K.; Kim, K.H.; Deep, A. Recent Advances in Enzyme Immobilization Techniques: Metal-Organic Frameworks as Novel Substrates. Coord. Chem. Rev. 2016, 322, 30-40. [CrossRef]

12. Gkaniatsou, E.; Sicard, C.; Ricoux, R.; Mahy, J.P.; Steuno, N.; Serre, C. Metal-Organic Frameworks: A Novel Host Platform for Enzymatic Catalysis and Detection. Mater. Horizon. 2017, 4, 55-63. [CrossRef]

13. Lian, X.; Fang, Y.; Joseph, E.; Wang, Q.; Li, J.; Banerjee, S.; Lollar, C.; Wang, X.; Zhou, H.C. Enzyme-MOF (Metal-Organic Framework) Composites. Chem. Soc. Rev. 2017, 46, 3386-3401. [CrossRef] [PubMed]

14. Bilal, M.; Adeel, M.; Rasheed, T.; Iqbal, H.M.N. Multifunctional Metal-Organic Frameworks-based Biocatalytic Platforms: Recent Developments and Future Prospects. J. Mater. Res. Technol. 2019, 8, 2359-2371. [CrossRef]

15. Drout, R.J.; Robison, L.; Farha, O.K. Catalytic Applications of Enzymes Encapsulated in Metal-Organic Frameworks. Coord. Chem. Rev. 2019, 381, 151-160. [CrossRef]

16. Liang, S.; Wu, X.; Xiong, J.; Zong, M.; Lou, W. Metal-Organic Frameworks as Novel Matrices for Efficient Enzyme Immobilization: An Update Review. Coord. Chem. Rev. 2020, 406, 213149. [CrossRef]

17. Gascón Pérez, V.; Sánchez-Sánchez, M. Environmentally Friendly Enzyme Immobilization on MOF Materials. Methods Mol. Biol. 2020, 2100, 271-296. [CrossRef]

18. Liu, W.L.; Yang, N.S.; Chen, Y.T.; Lirio, S.; Wu, C.Y.; Lin, C.H.; Huang, H.Y. Lipase-Supported Metal-Organic Framework Bioreactor Catalyzes Warfarin Synthesis. Chem. Eur. J. 2015, 21, 115-119. [CrossRef]

19. Shieh, K.; Wang, S.C.; Yen, C.I.; Wu, C.C.; Dutta, S.; Chou, L.Y.; Morabito, J.V.; Hu, P.; Hsu, M.H.; Wu, K.C.; et al. Imparting Functionality to Biocatalysts via Embedding Enzymes Into Nanoporous Materials by a De Novo Approach: Size-Selective Sheltering of Catalase in Metal-Organic Framework Microcrystals. J. Am. Chem. Soc. 2015, 137, 4276-4279. [CrossRef]

20. Castro-Miguel, E.; Gascon, V.; Sanchez-Sanchez, M.; Blanco, R.M.; Diaz-Garcia, M. General Method for Obtaining Biocatalysts which Comprises Enzyme Immobilization during the Synthesis of Metal-Organic Materials. WO Patent 2,016,193,516, 8 December 2016.

21. Gascon, V.; Castro-Miguel, E.; Diaz-Garcia, M.; Blanco, R.M.; Sanchez-Sanchez, M. In-situ and Post-Synthesis Immobilization of Enzymes on Nanocrystalline MOF Platforms to Yield Active Biocatalysts. J. Chem. Technol. Biotechnol. 2017, 92, 2583-2593. [CrossRef]

22. Gascon, V.; Carucci, C.; Jimenez, M.B.; Blanco, R.M.; Sanchez-Sanchez, M.; Magner, E. Rapid In Situ Immobilization of Enzymes in Metal-Organic Framework Supports under Mild Conditions. ChemCatChem 2017, 9, 1182-1186. [CrossRef]

23. Gascon, V.; Jimenez, M.B.; Blanco, R.M.; Sanchez-Sanchez, M. Semi-crystalline Fe-BTC MOF Material as an Efficient Support for Enzyme Immobilization. Catal. Today 2018, 304, 119-126. [CrossRef]

24. Sontz, P.A.; Bailey, J.B.; Ahn, S.; Tezcan, F.A. A Metal Organic Framework with Spherical Protein Nodes: Rational Chemical Design of 3D Protein Crystals. J. Am. Chem. Soc. 2015, 137, 11598-11601. [CrossRef] [PubMed]

25. Lykourinou, V.; Chen, Y.; Wang, X.S.; Meng, L.; Hoang, T.; Ming, L.J.; Musselman, R.L.; Ma, S. Immobilization of MP-11 Into a Mesoporous Metal-Organic Framework, MP-11@mesoMOF: A New Platform for Enzymatic Catalysis. J. Am. Chem. Soc. 2011, 133, 10382-10385. [CrossRef] [PubMed]

26. Chen, Y.; Lykourinou, V.; Vetromile, C.; Hoang, T.; Ming, L.J.; Larsen, R.W.; Ma, S. How Can Proteins Enter the Interior of a MOF? Investigation of Cytochrome c Translocation into a MOF Consisting of Mesoporous Cages with Microporous Windows. J. Am. Chem. Soc. 2012, 134, 13188-13191. [CrossRef] [PubMed]

27. Chen, Y.; Han, S.; Li, X.; Zhang, Z.; Ma, S. Why Does Enzyme Not Leach from Metal-Organic Frameworks (MOFs)? Unveiling the Interactions between an Enzyme Molecule and a MOF. Inorg. Chem. 2014, 53, 10006-10008. [CrossRef] 
28. Deng, H.; Grunder, S.; Cordova, K.E.; Valente, C.; Furukawa, H.; Hmadeh, M.; Gandara, F.; Whalley, A.C.; Liu, Z.; Asahina, S.; et al. Large-pore Apertures in a Series of Metal-Organic Frameworks. Science 2012, 336, 1018-1023. [CrossRef]

29. Sanchez-Sanchez, M.; Getachew, N.; Díaz, K.; Díaz-García, M.; Chebude, Y.; Díaz, I. Synthesis of Metal-Organic Frameworks in Water at Room Temperature: Salts as Linker Sources. Green Chem. 2015, 17, 1500-1509. [CrossRef]

30. Sanchez-Sánchez, M.; Diaz, I.; Getachew, N.; Chebude, Y. Procedimiento de Preparación de Compuestos Metalo-Orgánicos. ES Patent P201,231,968, 19 December 2012.

31. Sanchez-Sanchez, M.; de Asua, I.; Ruano, D.; Diaz, K. Direct Synthesis, Structural Features, and Enhanced Catalytic Activity of the Basolite F300-like Semiamorphous Fe-BTC Framework. Cryst. Growth Des. 2015, 15, 4498-4506. [CrossRef]

32. Guesh, K.; Caiuby, C.A.D.; Mayoral, A.; Diaz-Garcia, M.; Diaz, I.; Sanchez-Sanchez, M. Sustainable Preparation of MIL-100(Fe) and its Photocatalytic Behavior in the Degradation of Methyl Orange in Water. Cryst. Growth Des. 2017, 17, 1806-1813. [CrossRef]

33. Hu, X.; Lou, X.; Li, C.; Ning, Y.; Liao, Y.; Chen, Q.; Mananga, E.S.; Shen, M.; Hu, B. Facile Synthesis of the Basolite F300-like Nanoscale Fe-BTC Framework and its Lithium Storage Properties. RSC Adv. 2016, 6, 114483-114490. [CrossRef]

34. Shuai, W.; Das, R.K.; Naghdi, M.; Brar, S.K.; Verma, M. A Review on the Important Aspects of Lipase Immobilization on Nanomaterials. Biotechnol. Appl. Biochem. 2017, 64, 496-508. [CrossRef]

35. Fernández-Lafuente, R. Special Issue: Enzyme Immobilization 2016. Molecules 2017, 22, 601. [CrossRef] [PubMed]

36. Serra, E.; Mayoral, A.; Sakamoto, Y.; Blanco, R.M.; Diaz, I. Immobilization of Lipase in Ordered Mesoporous Materials: Effect of Textural and Structural Parameters. Microporous Mesoporous Mater. 2008, 114, 201-213. [CrossRef]

37. Samui, A.; Sahu, S.K. One-Pot Synthesis of Microporous Nanoscale Metal Organic Frameworks Conjugated with Laccase as a Promising Biocatalyst. New J. Chem. 2018, 42, 4192-4200. [CrossRef]

38. Jia, Y.; Chen, Y.; Lou, J.; Hu, Y. Immobilization of Laccase onto Meso-MIL-53(Al) via Physical Adsorption for the Catalytic Conversion of Triclosan. Ecotox. Environ. Saf. 2019, 184, 109670. [CrossRef]

39. Nowroozi-Nejad, Z.; Bahramian, B.; Hosseinkhani, S. A Fast and Efficient Stabilization of Firefly Luciferase on MIL-53(Al) via Surface Adsorption Mechanism. Res. Chem. Intermediat. 2019, 45, 2489-2501. [CrossRef]

40. Bradford, M.M. A Rapid and Sensitive Method for the Quantitation of Microgram Quantities of Protein Utilizing the Principle of Protein-Dye Binding. Anal. Biochem. 1976, 72, 248-254. [CrossRef]

41. Dhakshinamoorthy, A.; Alvaro, M.; Garcia, H. Commercial Metal-Organic Frameworks as Heterogeneous Catalysts. Chem. Commun. 2012, 48, 11275-11288. [CrossRef]

42. Martínez, F.; Leo, P.; Orcajo, G.; Díaz-García, M.; Sanchez-Sanchez, M.; Calleja, G. Sustainable Fe-BTC Catalyst for Efficient Removal of Mehylene Blue by Advanced Fenton Oxidation. Catal. Today 2018, 313, 6-11. [CrossRef]

43. Laemmlin, U.K. Cleavage of Structural Proteins during the Assembly of the Head of Bacteriophage T4. Nature 1970, 227, 680-685. [CrossRef] [PubMed]

(C) 2020 by the authors. Licensee MDPI, Basel, Switzerland. This article is an open access article distributed under the terms and conditions of the Creative Commons Attribution (CC BY) license (http://creativecommons.org/licenses/by/4.0/). 